Article

\title{
Structure and Phase Changes of Nickel Slag in Oxidation Treatment
}

\author{
Xiaoming Li, Xinyi Zhang, Xuyuan Zang and Xiangdong Xing *
}

School of Metallurgical Engineering, Xi'an University of Architecture and Technology; Xi'an 710055, China; xmli88@126.com (X.L.); zhangxyxinyi@163.com (X.Z.); JennieZang@163.com (X.Z.)

* Correspondence: xaxxd@xauat.edu.cn

Received: 26 February 2020; Accepted: 28 March 2020; Published: 31 March 2020

\begin{abstract}
To overcome the difficulty in the direct reduction of $\mathrm{Fe}_{2} \mathrm{SiO}_{4}$ in nickel slag, the isothermal oxidation of the nickel slag was conducted between 300 and $1000{ }^{\circ} \mathrm{C}$. Its morphology and phase composition after oxidation at $300-1000{ }^{\circ} \mathrm{C}$ for $5-30 \mathrm{~min}$ are analyzed by means of Scanning electron microscopy, X-ray diffraction, and thermodynamic calculation. The results show that oxidation can effectively promote the transformation of $\mathrm{Fe}^{2+}$ into $\mathrm{Fe}^{3+}$ in nickel slag. At $900{ }^{\circ} \mathrm{C}$, the oxidation rate of element $\mathrm{Fe}$ reaches $95 \%$. $\mathrm{Fe}^{2+}$ in $\mathrm{Fe}_{2} \mathrm{SiO}_{4}$ is oxidized to generate $\mathrm{Fe}_{2} \mathrm{O}_{3}$, and the unit cell volume decreases from $301.75 \AA^{3}$ to $297.72 \AA^{3}$ with the increase in temperature. At the same time, a large number of pores appear in the particle, which reduces the mass transfer resistance of gas in the particle during the reduction process, accelerates the reduction speed, and is conducive to strengthening the reduction. Therefore, the oxidation treatment of nickel slag can improve its phase composition, thus benefiting the subsequent reduction.
\end{abstract}

Keywords: oxidation; nickel slag; structure; phase; unit cell parameter

\section{Introduction}

The nickel slag discharged from the smelting process of nickel sulphide flash furnaces contains valuable metals such as iron, chromium and nickel, and is characterized by high iron grade, making itself an important secondary iron-containing resource [1,2]. However, at present, a considerable amount of nickel slag is piled up, occupying land and polluting the environment. Therefore, it is of economic value and environmental protection significance to utilize smelting slag as a resource. In the hope of extracting and utilizing metals in nickel slag, research has been carried out on leaching valuable metals using hydrometallurgical methods [3], extracting iron using smelting reduction [4,5] and preparing concentrate powder or ferroalloy using direct reduction plus magnetic separation [6,7]. Because of its simple technology, the direct reduction plus magnetic separation technology has been widely recognized by researchers in the realization of efficient separation of valuable elements in complex secondary iron-containing resources. Judging from the resource content, the extraction of iron from nickel slag is of most economic benefit. Nonetheless, iron in nickel slag exists in the form of $\mathrm{Fe}_{2} \mathrm{SiO}_{4}$, which is difficult to reduce. Therefore, it has become essential to investigate the additive enhanced reduction [8,9], mechanical activation enhanced reduction, and oxidation enhanced reduction of nickel slag.

Oxidation will enhance reducibility of the slag. In terms of the effect of oxidation on ore, scholars have actively researched, for example, with respect to the oxidation mechanism of ilmenite, the phase micro-transformation and the change in crystal structure behavior in the process of oxidation [10]. Moreover, some have explored the phase composition and morphology change when titania/ferrous oxide solution changed from $\mathrm{Fe}_{3} \mathrm{O}_{4}-\mathrm{Fe}_{2} \mathrm{TiO}_{4}$, titanomagnetite to a- $\mathrm{Fe}_{2} \mathrm{O}_{3}-\mathrm{FeTiO}_{3}$, titanohematite and pseudobrookite in the process of oxidation [11]. Meanwhile, others studied the 
effect of oxidation on the reduction behavior of special ilmenite in Panzhihua, and found that the new phases such as pseudorutile and $\mathrm{Fe}_{2} \mathrm{O}_{3}$ formed in the oxidation process of ilmenite destroyed the original mineral structure and improved the reduction efficiency [12]. A large number of studies have shown that oxidation can change the structure and phase composition of minerals, which is an effective way to strengthen reduction. Its actual effect depends on the type of minerals, original porosity, chemical composition, morphology of reduction products, properties of reducing agents and other factors [13-15]. However, regarding the study of oxidation of nickel slag, there has been a lack of detailed description of phase changes and crystal structure changes during the oxidation of nickel slag, let alone the thorough exploration of mechanism of oxidation. On the other hand, the study of nickel slag oxidation mechanism is of major significance for the comprehensive utilization of nickel slag.

This paper reports on a systematic study of the crystal structure behavior and phase transitions in nickel slag after treatment under different oxidation temperatures and intervals, to clarify the oxidation mechanism of nickel slag and provide a theoretical basis for the direct reduction and magnetic separation of nickel slag after oxidation to recover high-grade ferroalloy products.

\section{Materials and Methods}

\subsection{Experimental Materials}

Provided by a nickel smelter in Jinchuan, China, the original nickel slag was blocky. Its main components are listed in Table 1, and TFe refers to the total of iron. The nickel slag was mainly composed of iron, silicon, magnesium and calcium oxides. Fe in the slag was mainly in the form of $\mathrm{Fe}_{2} \mathrm{SiO}_{4}$, and there were also a small number of $\mathrm{Ni}, \mathrm{Cu}$, and other metal elements, thereby making nickel slag having recycling value.

Table 1. Chemical components of nickel slag (mass fraction, \%).

\begin{tabular}{ccccccccccc}
\hline Components & $\mathrm{TFe}$ & $\mathrm{FeO}$ & $\mathrm{SiO}_{2}$ & $\mathrm{MgO}$ & $\mathrm{Al}_{2} \mathrm{O}_{3}$ & $\mathrm{CaO}$ & $\mathrm{Ni}$ & $\mathrm{Cu}$ & $\mathrm{Co}$ & $\mathrm{S}$ \\
\hline wt. $\%$ & 39.40 & 49.68 & 32.50 & 9.70 & 2.30 & 1.20 & 0.455 & 0.338 & 0.144 & 0.868 \\
\hline
\end{tabular}

The X-ray diffraction (XRD, DMAX-RB12kW, Rigaku, Tokyo, Japan) analysis of the nickel slag was shown in Figure 1. Scanning electron microscopy (SEM, Nova400Nano, FEI, New York, NY, USA) image and element map were shown in Figure 2.

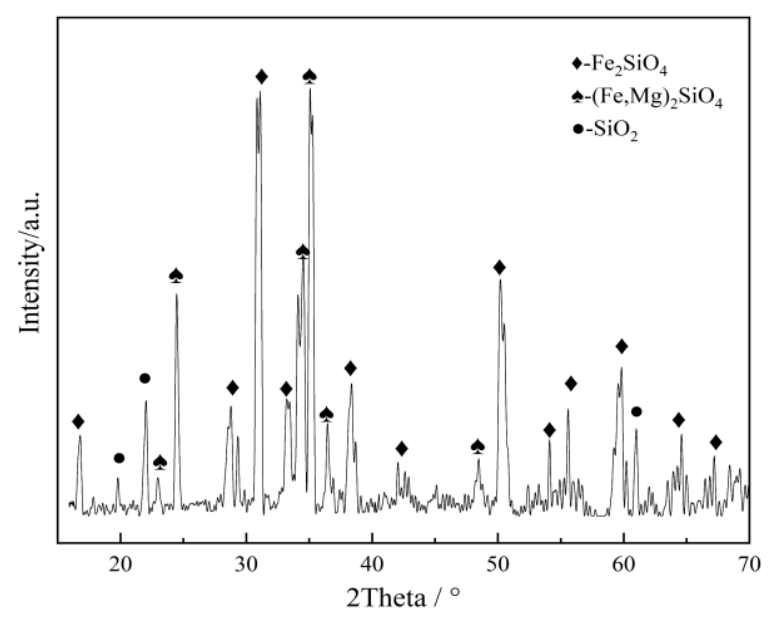

Figure 1. X-ray diffraction patterns of nickel slag sample.

X-ray diffraction inversion refinement method was used for quantitative phase analysis of various phases in nickel slag. It can be obtained that nickel slag mainly contains $59.9 \% \mathrm{Fe}_{2} \mathrm{SiO}_{4}, 38.4 \%$ $(\mathrm{Fe}, \mathrm{Mg})_{2} \mathrm{SiO}_{4}$, and $1.7 \% \mathrm{SiO}_{2}$. As seen in Figure 2, the nickel slag particles were dense in structure, 
and mainly consisted of elements $\mathrm{Fe}, \mathrm{O}$, and $\mathrm{Si}$ in large quantities, and elements $\mathrm{S}, \mathrm{Mg}$, and $\mathrm{Al}$ in small quantities. These particles were mainly composed of $\mathrm{Fe}_{2} \mathrm{SiO}_{4}$ formed by $\mathrm{Fe}, \mathrm{O}$, and $\mathrm{Si}$ and $(\mathrm{Fe}, \mathrm{Mg})_{2} \mathrm{SiO}_{4}$ formed by $\mathrm{Mg}, \mathrm{Fe}, \mathrm{O}$, and $\mathrm{Si}$. $\mathrm{SiO}_{2}$ formed by $\mathrm{O}$ and $\mathrm{Si}$ was uniformly distributed in the slag. $\mathrm{S}$ existed in the slag in the form of small particles, indicating that the sulfide and silicate did not form a solid solution.
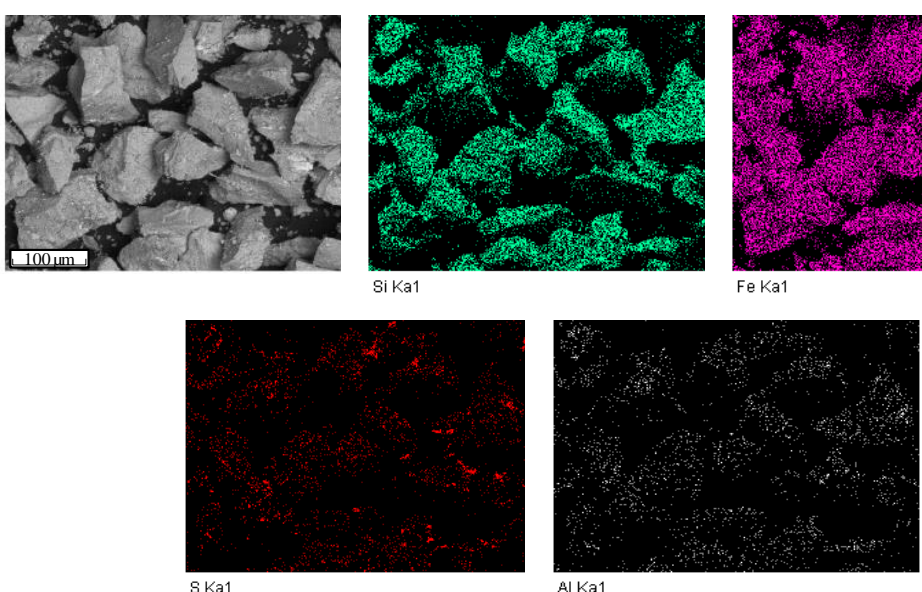

Al Ka1
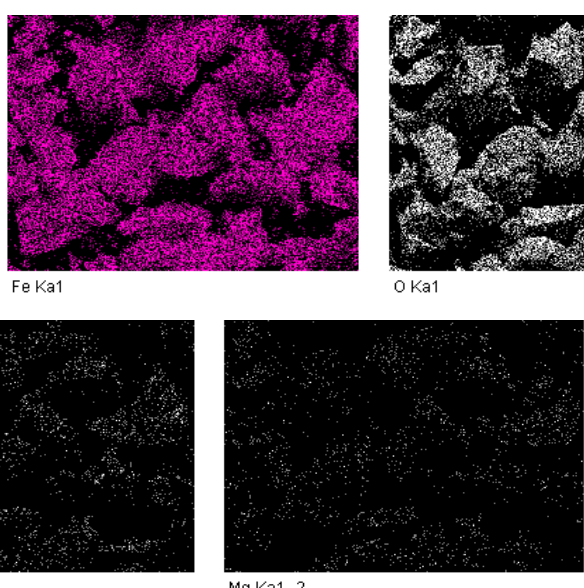

Mg Ka1 _2

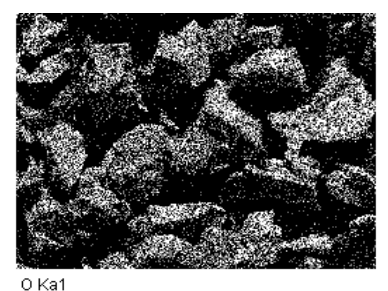

oKa1

Figure 2. Scanning electron microscopy (SEM) image and elemental map of nickel slag samples.

Particle size distribution of milled nickel slag and the equipment for nickel slag oxidation are shown in Figures 3 and 4, respectively.

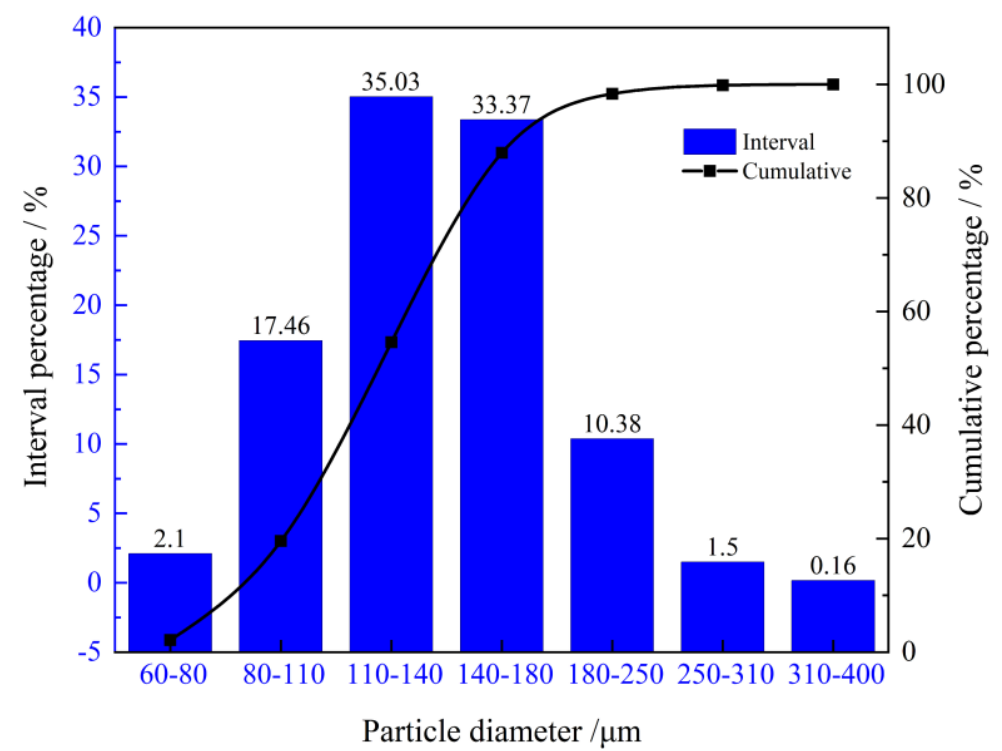

Figure 3. Particle size distribution of milled nickel slag. 


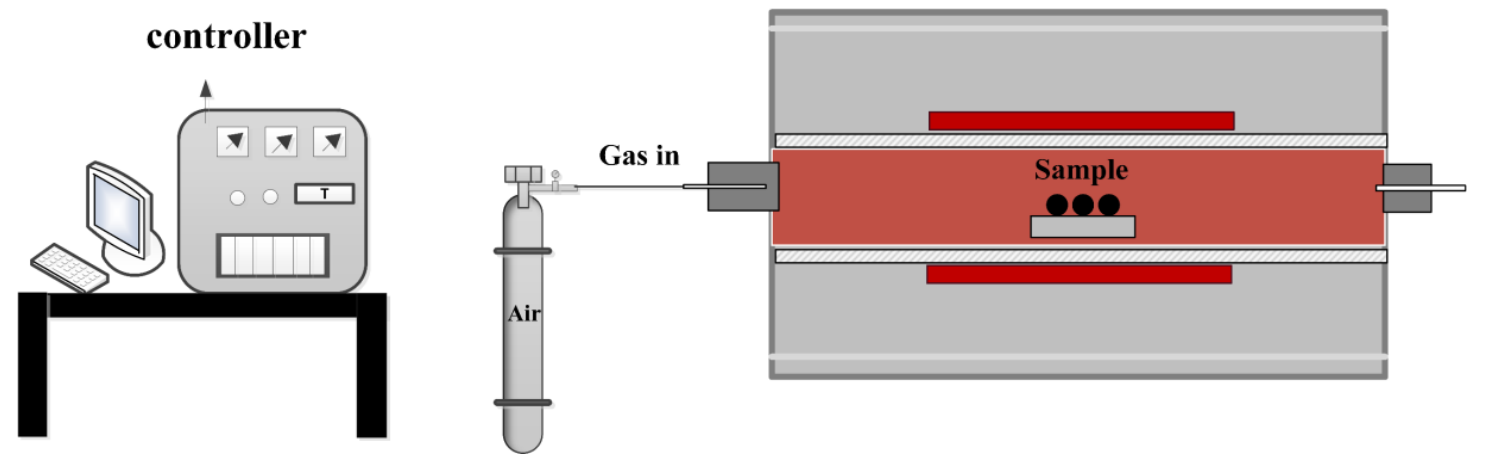

Figure 4. Equipment for nickel slag oxidation.

\subsection{Phase Structure Characterization}

After being oxidated under different conditions, the samples were cut along the radial axis. Half of them remained in the state of block, with their microstructure change to be observed by a scanning electron microscope (Nova400Nano, FEI, New York, NY, USA) and an energy dispersive spectrometer using an acceleration voltage of $15 \mathrm{kV}$. The mineral composition of the other half was analyzed by a rotating anode diffractometer (DMAX-RB12kW, Rigaku, Tokyo, Japan). The major measurement parameters were: $\mathrm{Cu}-\mathrm{K} \alpha$ radiation $\lambda=1.54050,42 \mathrm{kV}, 100 \mathrm{~mA}$, and step size $0.026^{\circ}$. The contents of $\mathrm{Fe}^{3+}$ and TFe in the samples were analyzed by composition analysis chemically.

$$
\alpha=\frac{\mathrm{Fe}^{3+}}{\mathrm{TFe}} \times 100 \%
$$

In Formula (1), $\alpha$ was the oxidation degree of $\mathrm{Fe}, \% ; \mathrm{Fe}^{3+}$ and TFe were the relative contents of $\mathrm{Fe}^{3+}$ and total iron in the oxidized nickel slag, respectively, \%, where $\mathrm{Fe}^{3+}=\mathrm{TFe}-\mathrm{Fe}^{2+}$.

\section{Results}

\subsection{Change in Fe Oxidation Rate in Oxidation}

Nickel slag samples were oxidized for 5-30 min at different temperatures, with their oxidation degree shown in Figure 5. The oxidation degree changed greatly with the increase in time and temperature. At a high temperature, the oxidation degree increased significantly in the first $5 \mathrm{~min}$. When the oxidation temperature reached $300{ }^{\circ} \mathrm{C}, 400{ }^{\circ} \mathrm{C}$, and $500{ }^{\circ} \mathrm{C}$, respectively, the oxidation degree increased slightly with the increase in oxidation time. When the reaction proceeded for 30 $\mathrm{min}$, the oxidation degree of nickel slag samples was in a slow rising tendency, namely less than $50 \%$. With the increase in oxidation temperature, the oxidation degree rose. When the temperature was $700{ }^{\circ} \mathrm{C}$, the oxidation degree varied considerably with time, and the oxidation degree was close to $70 \%$ after $30 \mathrm{~min}$ of reaction. The oxidation temperature increased to $900-1000{ }^{\circ} \mathrm{C}$, and the oxidation degree increased significantly, especially in the first $5 \mathrm{~min}$. The degree of oxidation tended to stabilize after 15 min of oxidation, reaching more than $95 \%$. This was due to the accelerating rate of molecular diffusion at high temperatures helping reach a high degree of oxidation in a short time. 


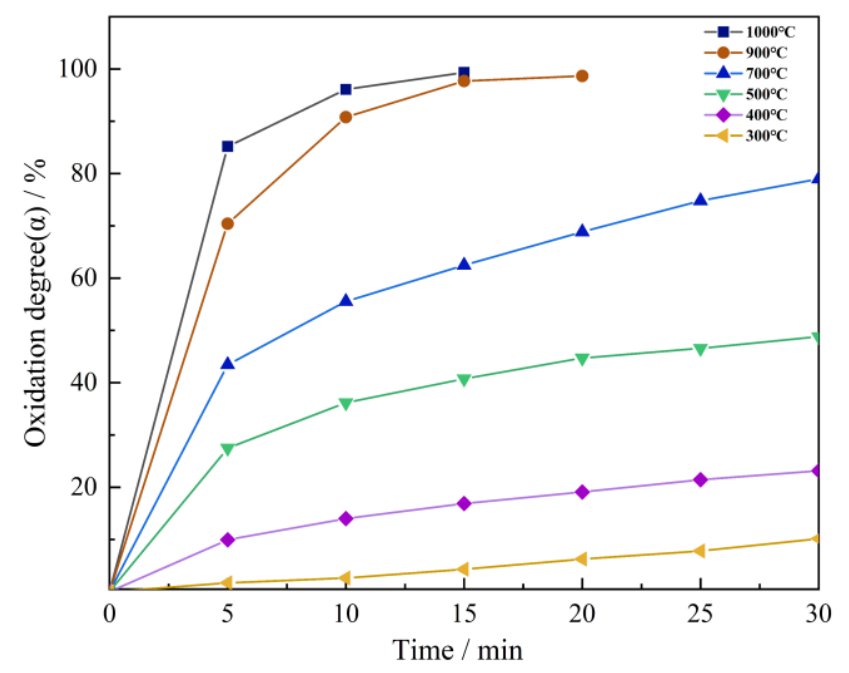

Figure 5. Fe oxidation rates of nickel slag samples after oxidation at different temperatures in different intervals.

\subsection{Phase Change in Oxidation}

Figure 6 exhibited the XRD analysis results of the phase composition of nickel slag samples after oxidation for $30 \mathrm{~min}$ at $300{ }^{\circ} \mathrm{C}, 400{ }^{\circ} \mathrm{C}, 500{ }^{\circ} \mathrm{C}, 700{ }^{\circ} \mathrm{C}, 900{ }^{\circ} \mathrm{C}$, and $1000{ }^{\circ} \mathrm{C}$, respectively. At $300{ }^{\circ} \mathrm{C}$, the degree of oxidation was low and the phase composition of samples remained basically unchanged. There only appeared a small number of characteristic peaks of $\mathrm{Fe}_{2} \mathrm{O}_{3}$ and characteristic diffraction peaks of $\mathrm{Fe}_{3} \mathrm{O}_{4}$. When the temperature increased to $500{ }^{\circ} \mathrm{C}$, the characteristic peaks of $\mathrm{Fe}_{3} \mathrm{O}_{4}$ increased slightly, while the characteristic diffraction peaks of $\mathrm{Fe}_{2} \mathrm{SiO}_{4}$ and $(\mathrm{Fe}, \mathrm{Mg})_{2} \mathrm{SiO}_{4}$ decreased significantly. When the oxidation temperature reached $700{ }^{\circ} \mathrm{C}$, the characteristic diffraction peak intensity of $\mathrm{Fe}_{3} \mathrm{O}_{4}$ and $\mathrm{Fe}_{2} \mathrm{O}_{3}$ found in the oxidized products increased further, while the characteristic peaks of $\mathrm{Fe}_{2} \mathrm{SiO}_{4}$ and $\mathrm{Fe}_{2} \mathrm{SiO}_{4}$ were not observed. The solid solution quantity of $\mathrm{MgO}$ in $\mathrm{Fe}_{2} \mathrm{SiO}_{4}$ dropped, and $\mathrm{Mg}$ mainly existed in the slag in the form of $\mathrm{Mg}_{2} \mathrm{SiO}_{4}$. As the oxidation temperature continued to go up to $900{ }^{\circ} \mathrm{C}$, no new phase was noticed in the oxidized products, and the characteristic peak intensity of high-valence iron oxides increased notably. At $1000^{\circ} \mathrm{C}$, the characteristic peak of each phase barely differed from that at $900{ }^{\circ} \mathrm{C}$. Therefore, the oxidation at $900{ }^{\circ} \mathrm{C}$ was preferred from the perspective of energy saving.

Figure 7 presented the XRD patterns of nickel slag samples after oxidation at $900{ }^{\circ} \mathrm{C}$ in different intervals. When oxidized at $900{ }^{\circ} \mathrm{C}$ for $5 \mathrm{~min}$, the samples consisted of a large amount of $\mathrm{Fe}_{3} \mathrm{O}_{4}$ and a small amount of $\mathrm{Fe}_{2} \mathrm{O}_{3}$. The rest of iron was mainly in the form of $(\mathrm{Fe}, \mathrm{Mg})_{2} \mathrm{SiO}_{4}$ and $\mathrm{Fe}_{2} \mathrm{SiO}_{4}$. When the oxidation time increased from $5 \mathrm{~min}$ to $10 \mathrm{~min}$, the characteristic diffraction peaks of $(\mathrm{Fe}, \mathrm{Mg})_{2} \mathrm{SiO}_{4}$ and $\mathrm{Fe}_{3} \mathrm{O}_{4}$ decreased slightly, while those of $\mathrm{Fe}_{2} \mathrm{O}_{3}$ seldom changed. When the oxidation time increased to $20 \mathrm{~min}$, the characteristic peaks of $\mathrm{Fe}_{3} \mathrm{O}_{4}, \mathrm{Fe}_{2} \mathrm{SiO}_{4}$ and $(\mathrm{Fe}, \mathrm{Mg})_{2} \mathrm{SiO}_{4}$ were not observed, while the intensity of the characteristic diffraction peaks of $\mathrm{Fe}_{2} \mathrm{O}_{3}$ increased significantly. With the increase in oxidation time, no new phase appeared. Therefore, it could be inferred that, after the oxidation of nickel slag at $900{ }^{\circ} \mathrm{C}$ for $20 \mathrm{~min}, \mathrm{Fe}^{2+}$ in the samples was completely oxidized to $\mathrm{Fe}^{3+}$. 


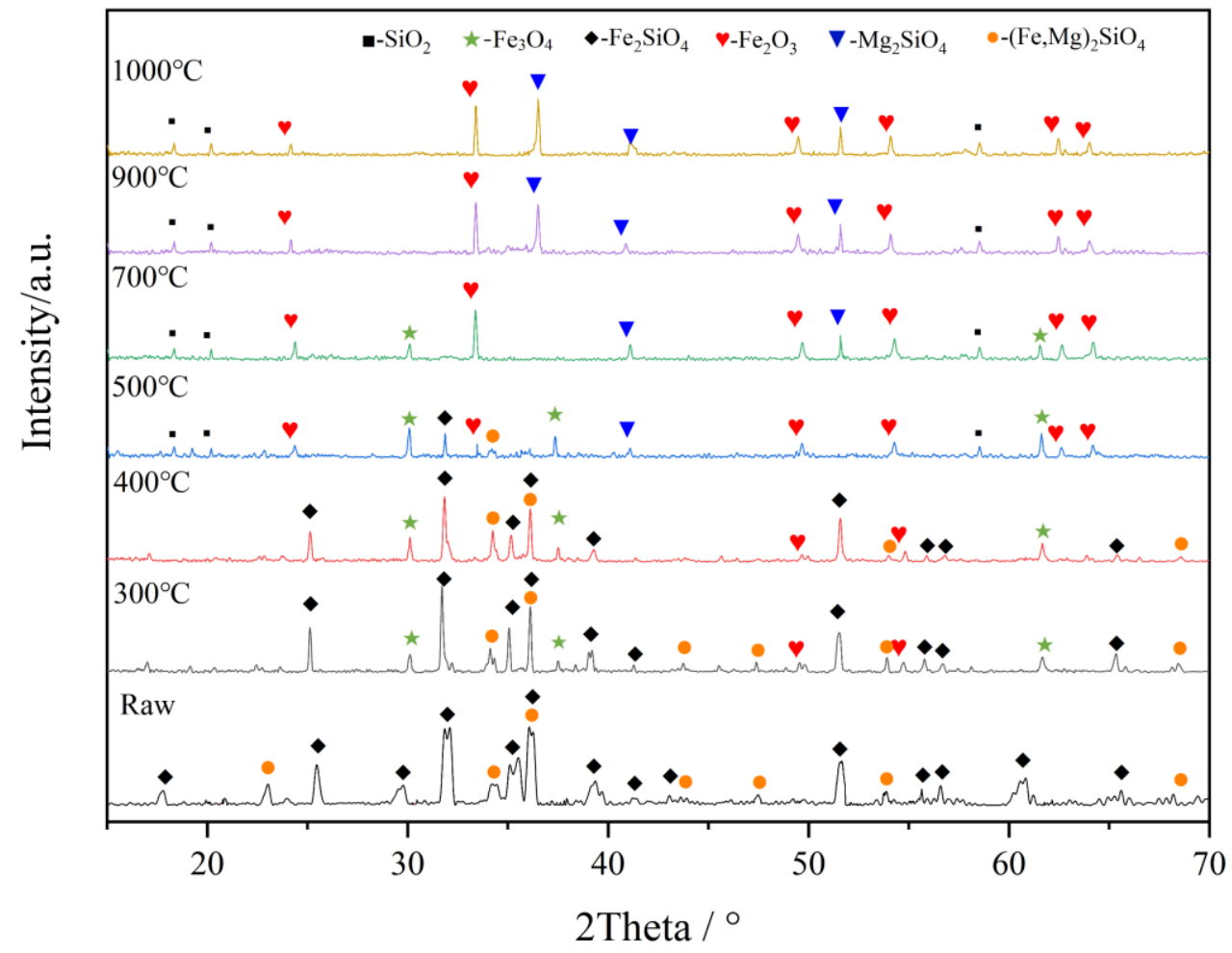

Figure 6. XRD patterns of nickel slag samples after oxidation for $30 \mathrm{~min}$ at different temperatures.

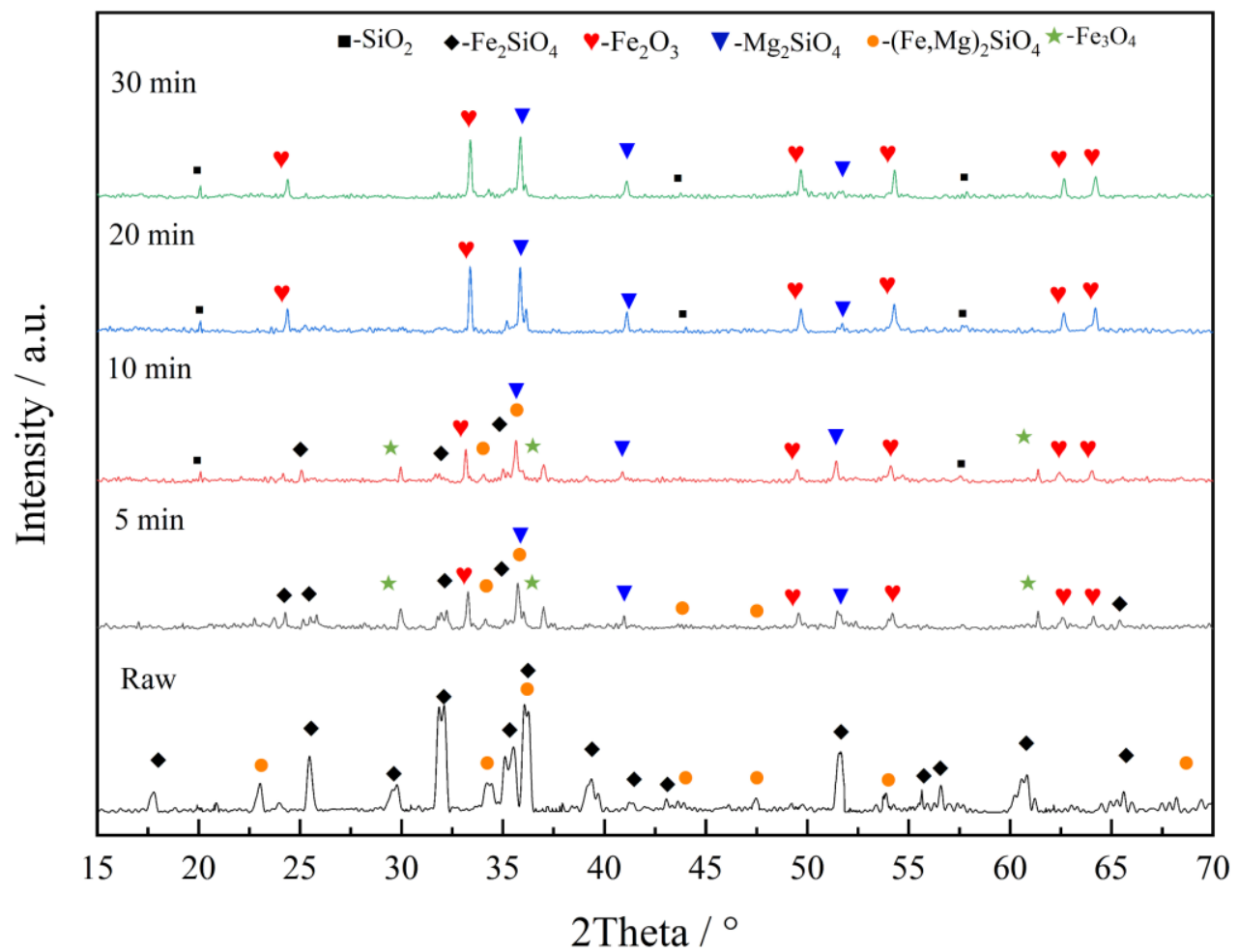

Figure 7. XRD patterns of nickel slag samples after oxidation at $900{ }^{\circ} \mathrm{C}$ in different intervals.

\subsection{Microstructure Change in Nickel Slag in Oxidation}

Nickel slag formed a new phase during oxidation, which would lead to the destruction of the original mineral structure. In order to confirm this hypothesis, the microstructure of oxidized samples 
was studied. Figure 8 showed the microstructure of nickel slag samples after oxidation for $20 \mathrm{~min}$ at $300^{\circ} \mathrm{C}, 400{ }^{\circ} \mathrm{C}, 500{ }^{\circ} \mathrm{C}, 700{ }^{\circ} \mathrm{C}, 900{ }^{\circ} \mathrm{C}$, and $1000^{\circ} \mathrm{C}$ respectively. To be specific, at an oxidation temperature of $300^{\circ} \mathrm{C}$, the sample structure barely changed, and the surface was relatively flat. It could be seen that a small number of white fine-grained iron oxides appeared on the surface of the nickel slag. When the oxidation temperature reached $400^{\circ} \mathrm{C}$, the morphology of samples varied significantly, and the surface became rough gradually. When the oxidation temperature continued to rise to $500{ }^{\circ} \mathrm{C}$, a large number of pores could be observed on the surface of samples, and the pore size was $\leq 2 \mu \mathrm{m}$ generally. When the oxidation temperature was $700{ }^{\circ} \mathrm{C}$, the pores began to extend to the interior, the samples became increasingly irregular in terms of structure and were finally concentrated in a network structure, and the pores gradually become larger. When the oxidation temperature rose to $900{ }^{\circ} \mathrm{C}$, the microstructure of the sample changed greatly. Porosity increases significantly, forming a large amount of hematite. However, when the oxidation temperature increased to $1000{ }^{\circ} \mathrm{C}$, the surface of samples showed a flaky structure and the pores declined.
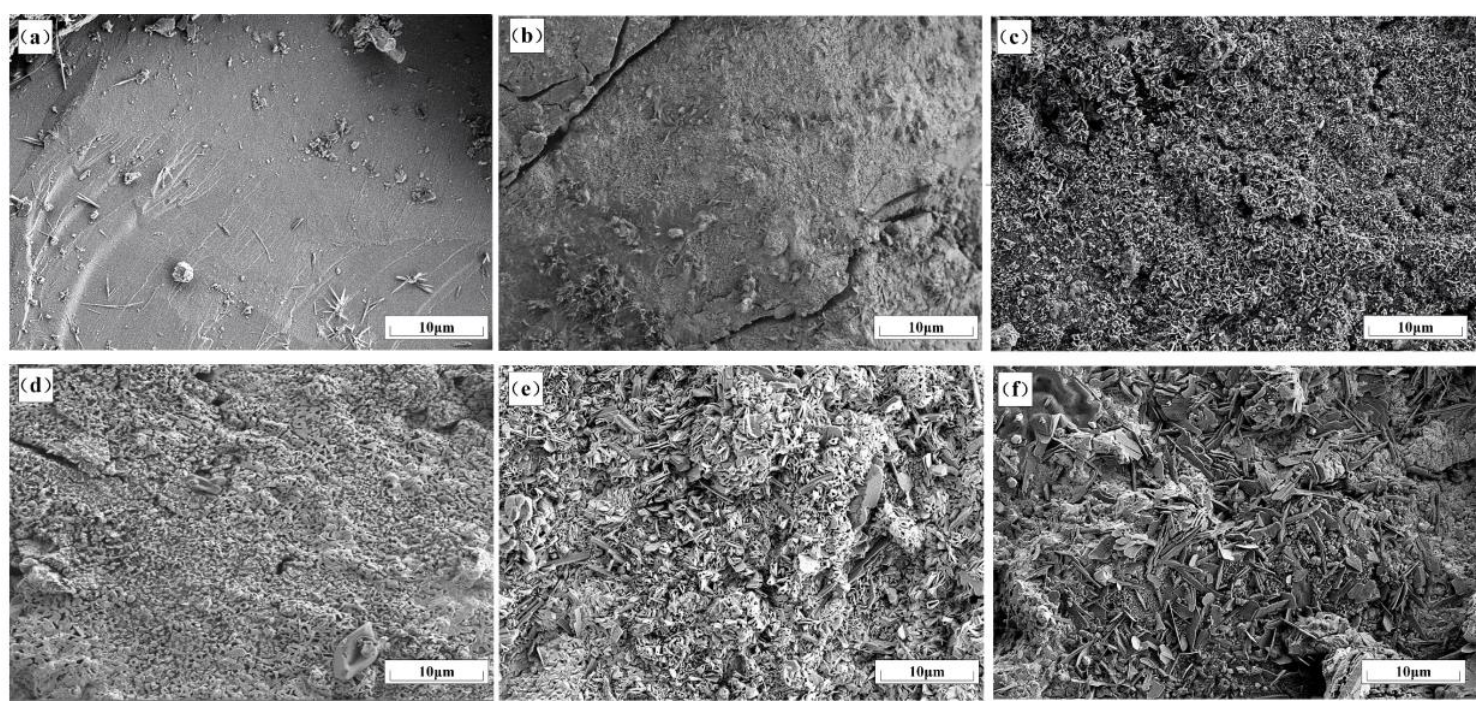

Figure 8. SEM morphology of nickel slag samples after oxidation for $20 \mathrm{~min}$ at different temperatures (a) $300{ }^{\circ} \mathrm{C}$; (b) $400{ }^{\circ} \mathrm{C}$; (c) $500{ }^{\circ} \mathrm{C}$; (d) $700{ }^{\circ} \mathrm{C}$; (e) $900{ }^{\circ} \mathrm{C}$; (f) $1000{ }^{\circ} \mathrm{C}$.

The SEM photos and analysis results of nickel slag samples after oxidation at $900{ }^{\circ} \mathrm{C}$ for $30 \mathrm{~min}$ were shown in Figure 9. Region a in Figure 9A was studied based on the energy spectrum analysis, results implied in Figure 9B. It was clear from the SEM image that flaky crystallites were formed. After oxidation, there were $\mathrm{O}, \mathrm{Fe}, \mathrm{Mg}, \mathrm{S}$, and other elements in the nickel slag, whose distribution was indicated by the results of surface scanning in the rectangular area. It could be clearly seen that Fe and $\mathrm{O}$ elements overlapped frequently, and that Fe in the nickel slag after oxidation mainly existed in the form of iron oxide. At the same time, $\mathrm{Mg}$ elements were distributed around $\mathrm{Fe}_{2} \mathrm{O}_{3}$ in the form of $\mathrm{Mg}_{2} \mathrm{SiO}_{4}$. 


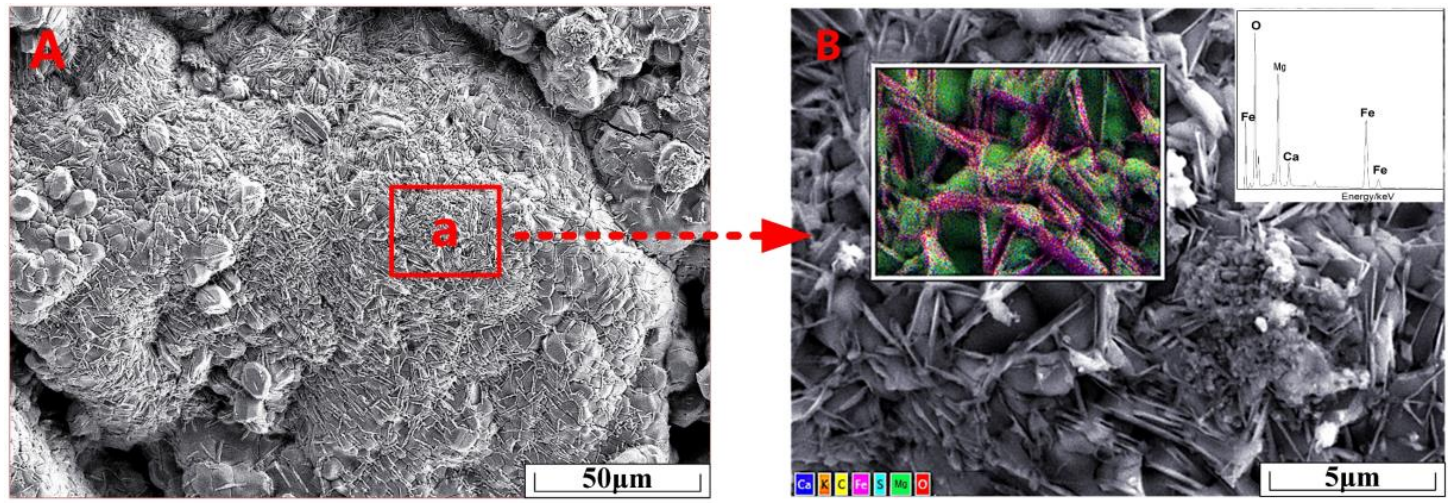

Figure 9. SEM and EDS analysis of nickel slag samples after oxidation at $900{ }^{\circ} \mathrm{C}$ for $30 \mathrm{~min}$. (A) SEM image of nickel slag samples; (B) energy-dispersive spectrum of region a.

\subsection{Crystal Structure Behavior during Oxidation in Nickel Slag}

The XRD analysis results of nickel slag samples after oxidation for $30 \mathrm{~min}$ at $400{ }^{\circ} \mathrm{C}$ and $900{ }^{\circ} \mathrm{C}$ respectively are shown in Figure 10. The microstructure of iron-containing phase in the nickel slag changed with the oxidation. Compared with $400{ }^{\circ} \mathrm{C}$, unstable $\beta-\mathrm{Fe}_{2} \mathrm{O}_{3}$ in the oxidized samples changed into stable $\alpha-\mathrm{Fe}_{2} \mathrm{O}_{3}$ when the oxidation temperature was $900{ }^{\circ} \mathrm{C}$; the decrease in unit cell volume of $\mathrm{Fe}_{2} \mathrm{O}_{3}$ was caused by the crystal transformation from cubic lattice into hexahedral lattice.

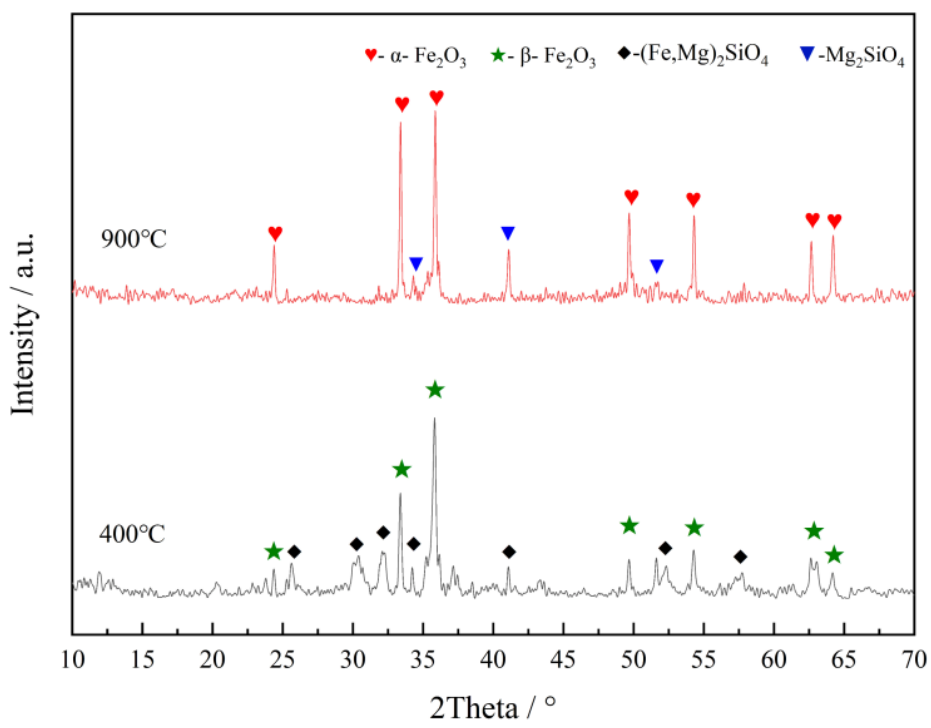

Figure 10. XRD patterns of nickel slag samples after oxidation for $30 \mathrm{~min}$ at $400{ }^{\circ} \mathrm{C}$ and $900{ }^{\circ} \mathrm{C}$ respectively.

In order to obtain accurate crystallographic parameter data, the nickel slag samples were scanned slowly. Through the XRD data, the unit cell dimension and volume (V) with the computational tolerances were determined, as observed in Tables 2-4.

Table 2. Unit cell parameters of $\mathrm{Fe}_{2} \mathrm{O}_{3}$ in nickel slag samples after oxidation at $400-1000{ }^{\circ} \mathrm{C}$.

\begin{tabular}{|c|c|c|c|c|c|c|c|}
\hline Temperature & $a / \AA ̊$ & Error/ \pm & $b / \AA$ & Error/ \pm & $c / \AA$ & Error/ \pm & Volume $/ \AA^{3}$ \\
\hline $400{ }^{\circ} \mathrm{C}$ & 5.0342 & 0.0055 & 5.0342 & 0.0036 & 13.7483 & 0.0012 & 301.75 \\
\hline $500{ }^{\circ} \mathrm{C}$ & 5.0330 & 0.0046 & 5.0330 & 0.0056 & 13.7396 & 0.0034 & 301.41 \\
\hline $700{ }^{\circ} \mathrm{C}$ & 5.0206 & 0.0082 & 5.0206 & 0.0062 & 13.7196 & 0.0011 & 299.49 \\
\hline $900{ }^{\circ} \mathrm{C}$ & 5.0065 & 0.0043 & 5.0065 & 0.0026 & 13.6411 & 0.0026 & 296.11 \\
\hline $1000^{\circ} \mathrm{C}$ & 5.0142 & 0.0085 & 5.0142 & 0.0024 & 13.6733 & 0.0016 & 297.72 \\
\hline ideal unit cell size & 5.0160 & - & 5.0160 & - & 13.6520 & - & 297.52 \\
\hline
\end{tabular}


Table 3. Unit cell parameters of $\mathrm{Fe}_{2} \mathrm{SiO}_{4}$ in nickel slag material and products after oxidation at $300-500{ }^{\circ} \mathrm{C}$.

\begin{tabular}{cccccccc}
\hline Temperature & $\boldsymbol{a} / \mathbf{\AA}$ & Error/ $\mathbf{\pm}$ & $\boldsymbol{b} / \mathbf{\AA}$ & Error/ \pm & $\boldsymbol{c} / \mathbf{\AA}$ & Error/ \pm & Volume $/ \AA^{\mathbf{3}}$ \\
\hline Raw & 5.7012 & 0.0030 & 10.3312 & 0.0028 & 4.7628 & 0.0046 & 302.59 \\
$300^{\circ} \mathrm{C}$ & 6.0797 & 0.0018 & 10.4601 & 0.0028 & 4.8152 & 0.0011 & 306.23 \\
$400^{\circ} \mathrm{C}$ & 6.0830 & 0.0012 & 10.4583 & 0.0018 & 4.8162 & 0.0007 & 306.40 \\
$500{ }^{\circ} \mathrm{C}$ & 6.1147 & 0.0047 & 10.4716 & 0.0055 & 4.8265 & 0.0025 & 309.03 \\
ideal unit cell size & 5.7060 & - & 10.3120 & - & 4.7620 & - & 301.70 \\
\hline
\end{tabular}

Table 4. Unit cell parameters of $\mathrm{Mg}_{2} \mathrm{SiO}_{4}$ in nickel slag samples after oxidation at $700-1000{ }^{\circ} \mathrm{C}$.

\begin{tabular}{|c|c|c|c|c|c|c|c|}
\hline Temperature & $a / \AA ̊$ & Error/ \pm & $b / \AA$ & Error/ \pm & $c / \AA ̊$ & Error/ \pm & Volume $/ \AA^{3}$ \\
\hline $700^{\circ} \mathrm{C}$ & 5.6972 & 0.0042 & 11.5185 & 0.0082 & 8.2440 & 0.0084 & 540.99 \\
\hline $900^{\circ} \mathrm{C}$ & 5.6939 & 0.0032 & 11.4198 & 0.0268 & 8.2973 & 0.0142 & 539.53 \\
\hline $1000^{\circ} \mathrm{C}$ & 5.6816 & 0.0056 & 11.4031 & 0.0198 & 8.2068 & 0.0204 & 538.72 \\
\hline ideal unit cell size & 5.6960 & - & 11.4440 & - & 8.2481 & - & 537.65 \\
\hline
\end{tabular}

According to Table 2, the unit cell volume of $\mathrm{Fe}_{2} \mathrm{O}_{3}$ decreased with the increase in oxidation temperature, and was gradually close to the ideal unit cell size of $\mathrm{Fe}_{2} \mathrm{O}_{3}\left(\mathrm{~V}=297.52 \AA^{3}\right)$. When the oxidation temperature increased from $400{ }^{\circ} \mathrm{C}$ to $1000{ }^{\circ} \mathrm{C}$, the unit cell parameters $a$ and $c$ of $\mathrm{Fe}_{2} \mathrm{O}_{3}$ decreased from $5.0342 \AA$ and $13.7483 \AA$ to $5.0142 \AA$ and $13.6733 \AA$, respectively, and the unit cell volume decreased from $301.75 \AA^{3}$ to $297.72 \AA^{3}$. Therefore, the deeper the oxidation degree of nickel slag samples was, the greater the lattice shrinkage along the $a$-axis and $c$-axis became, and the more the oxygen entering the lattice, the smaller the unit cell parameters $a$ value and volume became; and vice versa. Based on Table 3, the unit cell parameters of $\mathrm{Fe}_{2} \mathrm{SiO}_{4}$ in the samples without oxidation were close to the ideal size $\left(\mathrm{V}=301.70 \AA^{3}\right)$, indicating that element Fe in the samples was stable in the form of $\mathrm{Fe}_{2} \mathrm{SiO}_{4}$ at this time. When the oxidation temperature ranged between $300-500{ }^{\circ} \mathrm{C}$, the unit cell parameters of $\mathrm{Fe}_{2} \mathrm{SiO}_{4}$ increased gradually, with $a, b$ and $c$ increasing from $5.7012 \AA, 10.3312 \AA$ and $4.7628 \AA$ to $6.1147 \AA, 10.4716 \AA$ and $4.8265 \AA$ respectively; the unit cell volume increased from 302.59 $\AA^{3}$ to $309.03 \AA^{3}$, and deviated from the ideal value. With the increase in $\mathrm{Fe}_{2} \mathrm{SiO}_{4}$ unit cell volume, the stability of its structure was destroyed. More Fe elements in nickel slag existed in the form of iron oxide. According to Table 4, at an oxidation temperature of $700-1000{ }^{\circ} \mathrm{C}$, the unit cell volume of $\mathrm{Mg}_{2} \mathrm{SiO}_{4}$ declined slightly, with $a, b$ and $c$ decreasing from $5.6972 \AA, 11.5185 \AA$ and $8.2440 \AA$ to 5.6816 $\AA, 11.4031 \AA$ and $8.2068 \AA$ respectively; the unit cell volume decreased from $540.99 \AA^{3}$ to $538.72 \AA^{3}$, and was close to the ideal value $\left(\mathrm{V}=537.65 \AA^{3}\right)$. At this point, $\mathrm{Fe}^{2+}$ in the fayalite was oxidized to $\mathrm{Fe}^{3+}$, which caused the destruction of the structure of the fayalite, thus forming $\mathrm{Fe}_{2} \mathrm{O}_{3}$ and $\mathrm{Mg}_{2} \mathrm{SiO}_{4}$. As the oxidation temperature increased, the degree of oxidation increased, which meant that the increase in temperature was conducive to improving oxidation.

\subsection{Mechanism Analysis}

According to the XRD analysis of different oxidation temperatures, the following reactions occurred during the isothermal oxidation of nickel slag:

$$
\begin{gathered}
3 \mathrm{Fe}_{2} \mathrm{SiO}_{4}+\mathrm{O}_{2}=2 \mathrm{Fe}_{3} \mathrm{O}_{4}+3 \mathrm{SiO}_{2} \\
2 \mathrm{Fe}_{2} \mathrm{SiO}_{4}+\mathrm{O}_{2}=2 \mathrm{Fe}_{2} \mathrm{O}_{3}+2 \mathrm{SiO}_{2} \\
4 \mathrm{Fe}_{3} \mathrm{O}_{4}+\mathrm{O}_{2}=6 \mathrm{Fe}_{2} \mathrm{O}_{3}
\end{gathered}
$$

To better explore the oxidation process of $\mathrm{Fe}^{2+}$ in nickel slag, the "Reaction" module in FactSage 7.0 (Thermfact, Montreal, QC, Canada; GTT-Technologies, Ahern, Germany) was used to calculate the thermodynamic analysis of $\mathrm{Fe}_{2} \mathrm{SiO}_{4}$ oxidation. The results are shown in Figure 11. 


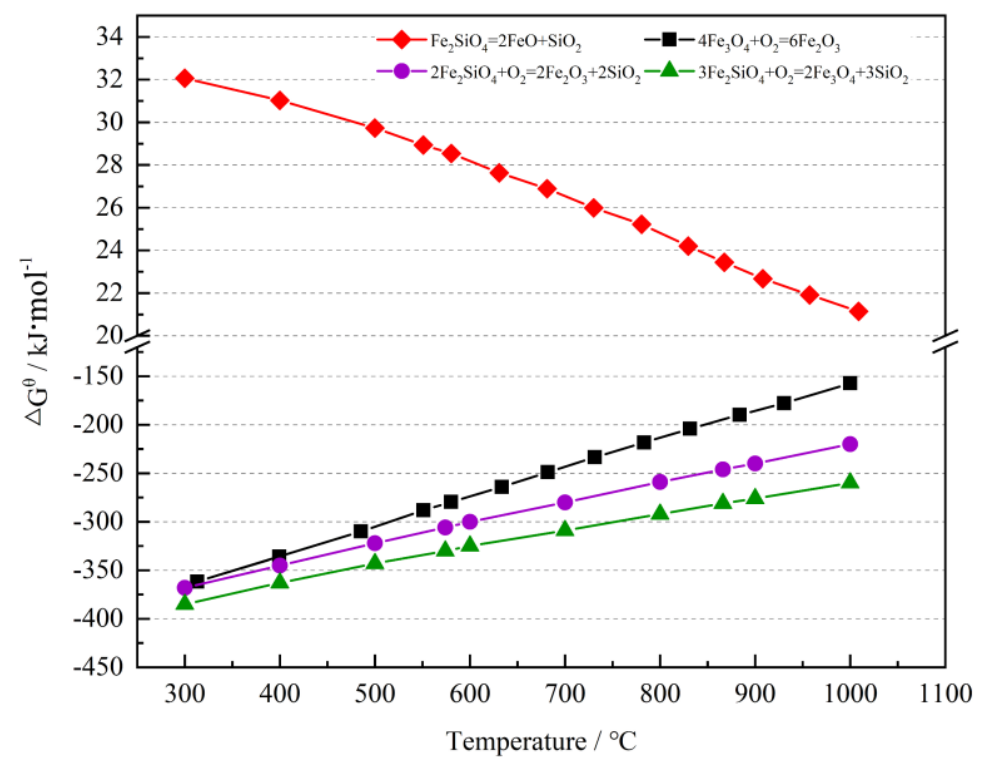

Figure 11. Decomposition of $\mathrm{Fe}_{2} \mathrm{SiO}_{4}$ in nickel slag and its standard Gibbs free energy change curve under oxidation atmosphere.

Figure 11 implies the relationship between the standard free energy $\left(\Delta \mathrm{G}^{\theta}\right)$ of $\mathrm{Fe}_{2} \mathrm{SiO}_{4}$ oxidation and temperature. It could be seen from Figure 11 that the $\Delta G^{\theta}$ resulting from the decomposition of $\mathrm{Fe}_{2} \mathrm{SiO}_{4}$ decreased with the increase in temperature. When the temperature was $1000^{\circ} \mathrm{C}$, the $\Delta \mathrm{G}^{\theta}$ was larger than 0, indicating that $\mathrm{Fe}_{2} \mathrm{SiO}_{4}$ was highly stable at high temperature and that it was difficult to dissociate free $\mathrm{FeO}$. This was mainly due to the complex structure of $\mathrm{Si}_{x} \mathrm{O}_{y}{ }^{z-}$ in water quenched nickel slag, which made $\mathrm{Fe}_{2} \mathrm{SiO}_{4}$ hard to decompose. $\mathrm{Fe}^{2+}$ in the nickel slag was oxidized to $\mathrm{Fe}_{3} \mathrm{O}_{4}$ by reaction Formula (2), thereby realizing the selective enrichment from iron to magnetite $\mathrm{Fe}_{3} \mathrm{O}_{4}$. Besides, the $\Delta \mathrm{G}^{\theta}$ of $\mathrm{Fe}_{3} \mathrm{O}_{4}$ generated by direct reaction of $\mathrm{Fe}_{2} \mathrm{SiO}_{4}$ was smaller than that of $\mathrm{Fe}_{2} \mathrm{O}_{3}$ generated by $\mathrm{Fe}_{3} \mathrm{O}_{4}$, which indicated that the formation and decomposition of iron oxides should follow the principle of gradual transformation: $\mathrm{Fe}_{2} \mathrm{SiO}_{4} \leftrightarrow \mathrm{Fe}_{3} \mathrm{O}_{4} \leftrightarrow \mathrm{Fe}_{2} \mathrm{O}_{3}$. The reaction mechanism is shown in Figure 12 .

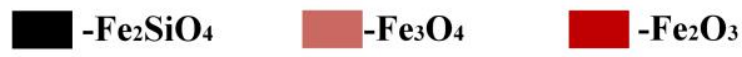

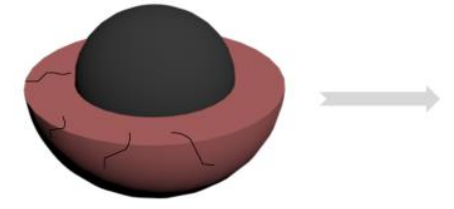

$2 \mathrm{Fe}_{2} \mathrm{SiO}_{4}+\mathrm{O}_{2}=2 \mathrm{Fe}_{3} \mathrm{O}_{4}+2 \mathrm{SiO}_{2}$

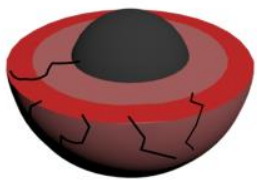

$4 \mathrm{Fe}_{3} \mathrm{O}_{4}+\mathrm{O}_{2}=6 \mathrm{Fe}_{2} \mathrm{O}_{3}$

Figure 12. Oxidation mechanism of nickel slag.

The final reaction products and structure of oxidation varied with the change in reaction temperature. After oxidation, phase transformation occurred, and the structure changed greatly, forming a large number of cracks which significantly increased the effective surface area of nickel slag, and further suggesting different controlling factors in the oxidation process. To go into detail, $\mathrm{Fe}_{2} \mathrm{SiO}_{4}$ produced fewer iron oxides at lower oxidation temperatures, at which point there were fewer cracks in the slag and lower porosity. When the oxidation temperature increased, a certain amount of 
oxide layer was produced in the slag and the surface roughness increased. At this time, the porosity increased, which was more conducive to the oxidation reaction.

\section{Conclusions}

(1) Oxidation can effectively promote the transformation of $\mathrm{Fe}^{2+}$ into $\mathrm{Fe}^{3+}$ in nickel slag. When the oxidation temperature is $900{ }^{\circ} \mathrm{C}$, the oxidation degree of the sample is improved. The extent of oxidation reaches $95 \%$ within 20 min.

(2) New phases are formed in the oxidation process, and the iron in the sample experiences the phase transformation $\mathrm{Fe}_{2} \mathrm{SiO}_{4} \rightarrow \mathrm{Fe}_{3} \mathrm{O}_{4} \rightarrow \mathrm{Fe}_{2} \mathrm{O}_{3}$. The increase in oxidation temperature is beneficial to the stability of $\mathrm{Fe}_{2} \mathrm{O}_{3}$, and the unit cell volume of $\mathrm{Fe}_{2} \mathrm{O}_{3}$ decreases from $301.75 \AA^{3}$ to $297.72 \AA^{3}$. However, after oxidation, the stability of $\mathrm{Fe}_{2} \mathrm{SiO}_{4}$ structure is destroyed, and the unit cell volume increases from $302.59 \AA^{3}$ to $309.03 \AA^{3}$. The amount of $\mathrm{Fe}_{2} \mathrm{SiO}_{4}$ decreases as iron is oxidized from $\mathrm{Fe}^{2+}$ to $\mathrm{Fe}^{3+}$.

(3) After oxidation, the structure of the sample changes significantly. The formation of a new phase destroys the original structure and forms a large number of pores inside the particles, increasing the specific surface area of particles and improving the gas diffusion conditions in the reduction process.

Author Contributions: Conceptualization, X.L. and X.Z. (Xinyi Zhang); methodology, X.L. and X.X.; software, X.Z. (Xinyi Zhang) and X.Z. (Xuyuan Zang); formal analysis, X.L. and X.Z. (Xinyi Zhang); investigation, X.Z. (Xinyi Zhang); resources, X.L.; data curation, X.X. and X.Z. (Xinyi Zhang); writing-original draft preparation, X.Z. (Xinyi Zhang) and X.Z. (Xuyuan Zang); writing - review and editing, X.Z. (Xinyi Zhang) and X.X.; supervision, X.L.; project administration, X.L.; funding acquisition, X.L. and X.X. All authors have read and agreed to the published version of the manuscript.

Funding: The work was supported by the Natural Science Foundation of China (No. 51774224).

Acknowledgments: The authors are grateful to JINCHUAN GROUP CO., LTD for providing the experimental materials.

Conflicts of Interest: The authors declare no conflict of interest.

\section{References}

1. Li, X.M.; Shen, M.; Wang, C.; Cui, Y.R.; Zhao, J.X. Current Situation and Development of Comprehensive Utilization of Nickel Slag. Int. Mater. Rev. 2017, 31, 100-105. [CrossRef]

2. Piatak, N.M.; Parsons, M.B.; Seal, R.R. Characteristics and environmental aspects of slag: A review. Appl. Geochem. 2015, 57, 236-266. [CrossRef]

3. Wang, Y.F. Industrial Study and Application on Recycling Valuable Metals in Nickel Leaching Slag. Copp. Eng. 2010, 2, 44-47.

4. Guo, Y.G.; Zhu, R.; Wang, Y. The fundamental research to extract iron from the nickel slag by smelting reduction process. Ind. Heat. 2015, 44, 40-43. (In Chinese)

5. Ni, W.; Ma, M.S.; Wang, Y.L. Thermodynamic and Kinetic in Recovery of Iron from Nickel Residue. J. Univ. Sci. Technol. Beijing 2009, 31, 163-168. [CrossRef]

6. Li, X.M.; Li, Y.; Zhang, X.Y.; Wen, Z.Y.; Xing, X.D. Growth characteristics of metallic iron particles in the direct reduction of nickel slag. MMTB 2020. [CrossRef]

7. Pan, J.; Zheng, G.L.; Zhu, D.Q.; Zhou, X.L. Utilization of nickel slag using selective reduction followed by magnetic separation. Trans. Nonferrous Met. Soc. China 2013, 23, 3421-3427. [CrossRef]

8. Li, X.M.; Wen, Z.Y.; Li, Y.; Wang, W.A.; Xing, X.D. Catalytic effect of sodium carbonate on the carbothermic reduction of nickel slag. Chin. J. Process Eng. 2020, 20, 182-188. (In Chinese) [CrossRef]

9. Li, X.M.; Wen, Z.Y.; Li, Y.; Yang, H.B.; Xing, X.D. Improvement of carbothermic reduction of nickel slag by addition of $\mathrm{CaCO}_{3}$. Trans. Nonferrous Met. Soc. China 2019, 29, 2658-2666. [CrossRef]

10. Wang, Z.Y.; Zhang, J.L.; Xing, X.D.; Liu, Z.J.; Zhang, Y.P.; Liu, X.L.; Liu, Y.R. Phase Transitions and Atomic-Scale Migration during the Oxidation of a Titania/Ferrous Oxide Solution. JOM 2015, 68, 656-667. [CrossRef]

11. Park, E.; Ostrovski, O. Effects of Oxidation of Titania Ferrous Ore on the Ore Structure and Reduction Behavior. ISIJ Int. 2004, 44, 74-81. [CrossRef] 
12. Guo, Y.F.; Lv, Y.N.; Jiang, T.; Qiu, G.Z. Effect of pre-oxidation on Panzhihua ilmenite in solid state reduction process. J. Univ. Sci. Technol. Beijing 2010, 32, 413-419. [CrossRef]

13. Liu, S.S.; Guo, Y.F.; Qiu, G.Z.; Jiang, T.; Chen, F. Solid-state reduction kinetics and mechanism of pre-oxidized vanadium-titanium magnetite concentrate. Trans. Nonferrous Met. Soc. China 2014, 24, 3372-3377. [CrossRef]

14. Xing, X.D.; Pang, Z.G.; Mo, C.; Wang, S.; Ju, J.T. Effect of $\mathrm{MgO}$ and $\mathrm{BaO}$ on viscosity and structure of blast furnace slag. J. Non-Cryst. Solids 2020, 530, 119801. [CrossRef]

15. Gou, H.P.; Zhang, G.H.; Chou, K.C. Influence of Pre-oxidation on Carbothermic Reduction Process of Ilmenite Concentrate. ISIJ Int. 2015, 55, 928-933. [CrossRef]

(C) 2020 by the authors. Licensee MDPI, Basel, Switzerland. This article is an open access article distributed under the terms and conditions of the Creative Commons Attribution (CC BY) license (http://creativecommons.org/licenses/by/4.0/). 